Research Paper

\title{
Anti-inflammatory effects of dexmedetomidine on human amnion-derived WISH cells
}

\author{
Sang-Hun Shin 1, Jae-Chaul You'1, Ji-Hye Ahn², Yeon Ha Kim³, Ji-Uk Yoon, Ah-Reum Cho5, Eun-Jung \\ $\mathrm{Kim}^{2 \bowtie}$ \\ 1. Department of Oral and Maxillofacial Surgery, School of Dentistry, Pusan National University, Yangsan, Korea. \\ 2. Department of Dental Anesthesia and Pain Medicine, School of Dentistry, Pusan National University, Dental Research Institute, Yangsan, Korea. \\ 3. Department of Integrated Biological Science, Pusan National University, Busan 46241, Korea. \\ 4. Department of Anesthesia and Pain Medicine, School of Medicine, Pusan National University, Yangsan, Korea. \\ 5. Department of Anesthesia and Pain Medicine, Pusan National University, School of Medicine, Yangsan, Republic of Korea.
}

$\square$ Corresponding author: Eun-Jung Kim, Department of Dental Anesthesia and Pain Medicine, School of Dentistry, Pusan National University, Dental Research Institute, Geumo-ro 20, Yangsan, Gyeongnam, 50612, Republic of Korea. Tel: +82-55-360-5370; Fax: +82-55-360-5369.

(1) The author(s). This is an open access article distributed under the terms of the Creative Commons Attribution License (https://creativecommons.org/licenses/by/4.0/). See http://ivyspring.com/terms for full terms and conditions.

Received: 2020.06.25; Accepted: 2020.08.24; Published: 2020.09.09

\begin{abstract}
Background: To maintain the normal pregnancy, suppression of inflammatory signaling pathway is a crucial physiologic response. Dexmedetomidine has been used for labor analgesia or supplement of inadequate regional analgesia during delivery. And it has been reported that dexmedetomidine has an anti-inflammatory effect. In this study, we examined the influence of dexmedetomidine on the expression of cyclooxygenase-2 (COX-2), prostaglandin $E_{2}\left(P_{2} E_{2}\right)$ and inflammatory cytokines in lipopolysaccharide (LPS)-stimulated human amnion-derived WISH cells. In addition, we evaluated the association of mitogen-activated protein kinase (MAPK) and nuclear factor kappa B (NF-KB) pathway in anti-inflammatory effect of dexmedetomidine.

Methods: Human amnion-derived WISH cells were pretreated with various concentrations of dexmedetomidine $(0.001-1 \mu \mathrm{g} / \mathrm{ml})$ for $1 \mathrm{~h}$ and after then treated with LPS $(1 \mu \mathrm{g} / \mathrm{ml})$ for $24 \mathrm{~h}$. MTT assay was conducted to evaluate the cytotoxicity. Nitric oxide (NO) production was analyzed using Griess-reaction microassay. RT-PCR was performed for analysis of mRNA expressions of COX-2, PGE tumor necrosis factor (TNF)- $\alpha$ and interlukin (IL)-1 $\beta$. Protein expressions of COX-2, PGE 2 , P38 and NF-KB were analyzed by western blotting.

Results: LPS and dexmedetomidine had no cytotoxic effect on WISH cells. There was no difference in NO production after dexmedetomidine pretreatment. The mRNA and protein expressions of COX-2 and $\mathrm{PGE}_{2}$ were decreased by dexmedetomidine pretreatment in LPS-treated WISH cells. Dexmedetomidine also attenuated the LPS-induced mRNA expression of TNF- $\alpha$ and IL-1 $\beta$. The activation of $\mathrm{p} 38$ and NF-KB was suppressed by dexmedetomidine pretreatment in LPS-treated WISH cells.

Conclusion: We demonstrated that dexmedetomidine pretreatment suppressed the expressions of inflammatory mediators increased by LPS. In addition, this study suggests that anti-inflammatory effect of dexmedetomidine on WISH cells was mediated by the inhibitions of p38 and NF-KB activation.
\end{abstract}

Key words: Amnion, Dexmedetomidine, Inflammation, p38, NF-кB

\section{Introduction}

The endogenous levels of prostaglandins (PGs) in the endometrial decidua of pregnant women are 200-fold lower than that of non-pregnant women [1]. The selective epigenetic silencing of the key inflammatory chemokine genes that attract $\mathrm{T}$ cells in the decidual stroma is maintained during normal pregnancy [2]. The suppression of inflammatory signaling pathways is critical for maintaining normal pregnancy. The levels of PGs in the plasma, urine, and amniotic fluid increase before the onset of labor 
leading to the rupture of the fetal membrane, cervical dilatation, and myometrial contractions [3, 4]. The administration of exogenous PGs or the failure to inhibit PG production can result in spontaneous abortion [5]. Besides PGs, nitric oxide (NO) is one of the factors involved in the maintenance of normal pregnancy. $\mathrm{NO}$ is a short-lived free radical generated from L-arginine and preserves the uterine relaxation during pregnancy $[6,7]$. Although NO is known as a relaxing factor in the myometrium, it is not clear how $\mathrm{NO}$ production is altered by an inflammatory response.

Inflammation has been recognized as a defensive immune response against pathogens. During intrauterine infections, innate immune responses activate inflammatory reactions leading to the secretion of pro-inflammatory cytokines that initiate the signaling pathway leading to preterm labor [8]. The inflammatory reaction is enhanced by various molecules. Reactive oxygen species (ROS) is a molecule involved in the progression of inflammatory responses. Antioxidant molecules can reduce oxidative stress by ROS and suppress inflammatory responses [9]. Bacterial components such as lipopolysaccharide (LPS) and lipoteichoic acids are pathogen-associated molecules that trigger inflammatory responses $[10,11]$.

LPS is the most abundant component of the outer membrane of gram-negative bacteria. It is a key stimulator of acute inflammatory responses and triggers the release of various pro-inflammatory cytokines including tumor necrosis factor-alpha (TNF- $\alpha$ ), interleukin (IL)-1 $\beta$, and IL-6 [12-14]. Toll-like receptor 4 (TLR4) is an innate LPS-pattern recognition receptor that is important for a rapid immune response and proper bacterial clearance [15]. During LPS-induced inflammatory response, the binding of LPS to TLR4 leads to the activation of the mitogen-activated protein kinase (MAPK) and nuclear factor kappa B (NF-kB) signaling pathways $[16,19]$. LPS also enhances the production of the cyclooxygenase-2 (COX-2) that is essential for the production of PGs [18]. Based on this evidence, we treated WISH cells with LPS to induce an inflammatory response and expected that activation of MAPK and NF-kB may be affected by the LPS-induced inflammatory process.

Dexmedetomidine is a highly selective $a-2$ adrenoreceptor agonist that has been used for achieving sedation, anxiolysis, and analgesia in intensive care units (ICUs) or during operative procedures. Compared to other sedative drugs, dexmedetomidine has a low risk of respiratory depression [19,20]. Consequently, the use of dexmedetomidine in ICUs and procedural sedation has increased. Previous studies reported that dexmedetomidine has anti-inflammatory effects; dexmedetomidine was shown to decrease the secretion of inflammatory cytokines and consequently suppress inflammatory responses in animal experiments and clinical studies [21,22]. Dexmedetomidine can be administered to pregnant women for labor analgesia when the patient refuses epidural or spinal anesthesia or as a supplement to inadequate epidural analgesia. However, physicians are reluctant to use dexmedetomidine in pregnancy because of the possibility of uteroplacental transfer and the effects on the fetus [23].

This study was conducted to investigate the effect of dexmedetomidine on the expression of inflammatory mediators in LPS-stimulated human amnion-derived WISH cells. The involvement of the MAPK and NF-KB signaling pathways in the anti-inflammatory effect of dexmedetomidine was examined.

\section{Materials and Methods}

\section{Cell culture}

The WISH human amnion cell line was purchased from the American Type Culture Collection (ATCC; Manassas, VA, USA) and cultured in Eagle's Minimum Essential Medium (ATCC) supplemented with $10 \%$ fetal bovine serum (Gibco, Carlsbad, CA, USA) at $37{ }^{\circ} \mathrm{C}$ in an atmosphere of $5 \%$ $\mathrm{CO}_{2}$. The WISH culture was subcultured (passaged) once every 3 days.

\section{Dexmedetomidine treatment}

A commercially available formulation of dexmedetomidine hydrochloride (KyongBo Pharm, Chungnam, Korea) was used in this study. The formulation was diluted with the culture medium and added to the cultures at concentrations of $0.001,0.01$, 0.1 , and $1 \mu \mathrm{g} / \mathrm{mL}$ and incubated for $1 \mathrm{~h}$ followed by treatment with the growth medium or $1 \mu \mathrm{g} / \mathrm{mL}$ LPS (Sigma, St. Louis, MO, USA) for $24 \mathrm{~h}$.

\section{Nitric oxide (NO) assay}

To evaluate the effect of pretreatment with dexmedetomidine on the production of $\mathrm{NO}$ in LPS-treated WISH cells, the Griess reaction microassay (Cell Signaling Technology) was performed. WISH cells were seeded on 24-well plates at a density of $1 \times 10^{4}$ cells/well. The concentration of $\mathrm{NO}$ in the culture supernatant was estimated from the concentration of nitrites $\left(\mathrm{NO}_{2}{ }^{-}\right)$that are stable end-products of NO metabolism. WISH cells were pretreated with dexmedetomidine at concentrations ranging between 0.01 and $1 \mu \mathrm{g} / \mathrm{mL}$ for $1 \mathrm{~h}$ and subsequently incubated with $1 \mu \mathrm{g} / \mathrm{mL}$ LPS for $24 \mathrm{~h}$. 
Following incubation, the supernatants were collected and mixed with an equal volume (1:1) of Griess reagent. The samples were incubated at room temperature for $10 \mathrm{~min}$ and their absorbance was measured at $540 \mathrm{~nm}$ using a microplate reader (Bio-Rad Model 680; Bio-Rad, Hercules, CA, USA).

\section{MTT assay}

WISH cells were seeded in 24-well plates at a density of $1 \times 10^{5}$ cells/well and cultured for $24 \mathrm{~h}$ at 37 ${ }^{\circ} \mathrm{C}$ in an incubator with an atmosphere of $5 \% \mathrm{CO}_{2}$. The cells were subsequently exposed to dexmedetomidine at concentrations ranging between 0.001 and $1 \mu \mathrm{g} / \mathrm{mL}$ for $3 \mathrm{~h}$. Following dexmedetomidine treatment, the MTT [3-(4,5-dimethylthiazol- 2-yl) -2,5-diphenyl tetrazolium bromide; Affymetric, Inc. USB, OH, USA] assay was performed by adding $100 \mu \mathrm{L}$ MTT solution (5 mg/mL in PBS at $\mathrm{pH} 7.4$ ) to each well and incubating at $37^{\circ} \mathrm{C}$. The medium was removed after 1 $\mathrm{h}$ and $100 \mu \mathrm{L}$ dimethyl sulfoxide (DMSO; Biosesang, Seongnam, Korea) was added to each well. The plate was gently rotated on an orbital shaker for $15 \mathrm{~min}$ to dissolve the precipitate. The absorbance was measured at $540 \mathrm{~nm}$ with a microplate reader (Bio-Rad Model 680). All the experiments were performed at least three times.

\section{RNA isolation and reverse transcriptase- polymerase chain reaction (RT-PCR)}

WISH cells were seeded in a 12-well cell-culture plate at a density of $5 \times 10^{5}$ cells/well. After $1 \mathrm{~h}$ of treatment with dexmedetomidine, the cells were treated with LPS for $24 \mathrm{~h}$. Following LPS treatment, the total RNA was isolated using $500 \mu \mathrm{L}$ of TRIzol reagent (Invitrogen, Carlsbad, CA, USA). The total mRNA $(1 \mu \mathrm{g})$ was used as the template for cDNA synthesis using oligo(dT) PrimeScript ${ }^{\mathrm{TM}} 1$ st strand cDNA Synthesis Kits (TaKaRa Clontech, BD Biosciences, Palo Alto, CA, USA) according to the manufacturer's instructions. RT-PCR was performed on a SimpliAmp Thermal Cycler (Applied Biosystems, Life Science Technologies, CA, USA). The primers used for PCR were: IL-1 $\beta$, Forward: 5'-CTC GCCAGTGAAATGATGGCT-3', Reverse: 5'-GTCGG AGATTCGTAGCTGGAT-3'; TNF-a, Forward: 5'-CCA GGCAGTCAGATCATCTTC-3', Reverse: 5'-GTTATC TCTCAGCTCCACGC-3'; $\beta$-actin, Forward: 5'-GACCT GACTGACTACCTCATG-3', Reverse: 5'-CGCTCATT GCCAATGGTGATG-3'. IL-1 $\beta / \beta$-actin was amplified using 35 cycles of PCR at $95^{\circ} \mathrm{C}$ for $30 \mathrm{~s}, 55^{\circ} \mathrm{C}$ for $30 \mathrm{~s}$, and $72{ }^{\circ} \mathrm{C}$ for $30 \mathrm{~s}$, and the final extension was performed at $72{ }^{\circ} \mathrm{C}$ for $7 \mathrm{~min}$. TNF- $\alpha / \beta$-actin was amplified using 35 cycles of PCR at $94^{\circ} \mathrm{C}$ for $30 \mathrm{~s}, 54$ ${ }^{\circ} \mathrm{C}$ for $30 \mathrm{~s}$, and $72{ }^{\circ} \mathrm{C}$ for $30 \mathrm{~s}$, with the final extension performed at $72{ }^{\circ} \mathrm{C}$ for $10 \mathrm{~min}$. The PCR products were separated on a $1.5 \%$ stained agarose gel. They were assayed using a Gel Doc ImageQuant LAS 500 System (GE Healthcare Bio-Sciences AB, Uppsala, Sweden). $\beta$-actin was used for normalizing all the target genes. The data were analyzed using ImageJ software (National Institutes of Health, Bethesda, MD, USA).

\section{Western blotting}

All the cells were extracted with chilled RIPA buffer $(50 \mathrm{mM}$ Tris at $\mathrm{pH} 7.5,150 \mathrm{mM} \mathrm{NaCl}, 5 \mathrm{mM}$ EDTA, $0.5 \%$ NP40, $5 \mathrm{mM}$ DTT, $0.2 \mathrm{mM}$ sodium orthovanadate, $100 \mathrm{mM} \mathrm{NaF}$, and $1 \mathrm{mM}$ PMSF) containing $1 \mathrm{X}$ protease inhibitor/phosphatase inhibitor cocktail (Cell Signaling Technology). The samples $(25 \mu \mathrm{g}$ protein/well) were separated by sodium dodecyl sulfate-polyacrylamide gel electrophoresis and transferred to nitrocellulose membranes (GE Healthcare, Chicago, IL, USA). The membranes were blocked with TBS- $0.1 \%$ Tween-20 (TBST) containing 3\% skim milk for $1 \mathrm{~h}$. The membranes were subsequently incubated overnight with a-tubulin (1:1000; Santa Cruz, CA, USA), p38 MAPK (1:1000; Cell Signaling Technology), phosphop38 MAP kinase (1:500; Cell Signaling Technology), NF-kB p65 (1:1000; Santa Cruz), phospho-NF-kB p65 27. Ser 536 (1:500; Santa Cruz), PGE synthase 2 (A-2) (1:1000; Cell Signaling Technology), and COX-2 (D5H5) rabbit mAb (1:1000; Santa Cruz) antibodies at $4{ }^{\circ} \mathrm{C}$ in TBST with $3 \%$ skim milk. After washing three times with TBST, the membranes were incubated with horseradish peroxidase-conjugated anti-rabbit (1:1000; Enzo Life Sciences, Plymouth Meeting, PA, USA) and anti-mouse (1:1000; Santa Cruz) antibodies for $1 \mathrm{~h}$ at room temperature. The membranes were subsequently washed three times with TBST and the bands were visualized using ECL detection reagents (Promega, Madison, WI, USA). The expression of a-tubulin was used as a control. The target-protein bands were normalized relative to the control band with ImageJ software.

\section{Statistical analyses}

Data are presented as the mean \pm standard deviation (SD). All the experiments were repeated at least three times. The statistical analyses were performed using the SigmaPlot v10 software. $P$ value of $<0.05$ was considered to be statistically significant.

\section{Results}

\section{Cytotoxicity of LPS and dexmedetomidine pretreatment in WISH cells}

The MTT assay was performed for assessing the cytotoxicity of LPS and dexmedetomidine pretreatment in WISH cells. WISH cells were treated with 
concentrations of dexmedetomidine ranging between 0.001 and $1 \mu \mathrm{g} / \mathrm{mL}$ followed by treatment with 1 $\mu \mathrm{g} / \mathrm{mL}$ LPS. As shown in Figure 1, LPS and dexmedetomidine pretreatment did not affect the viability of WISH cells indicating that LPS and dexmedetomidine were not cytotoxic to WISH cells.

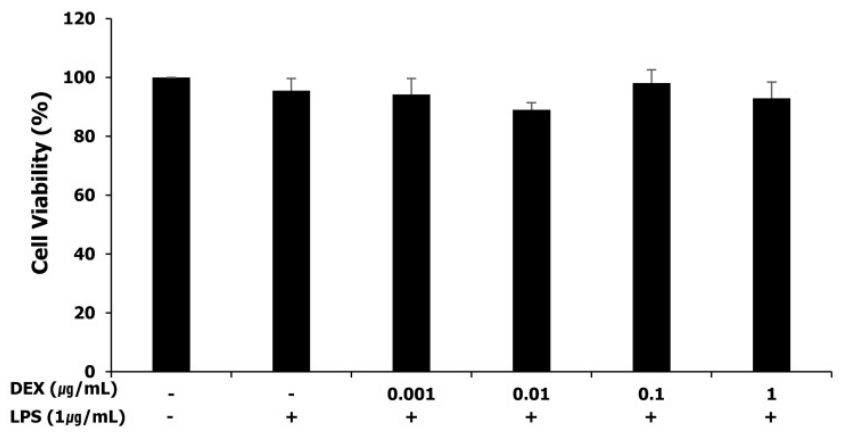

Figure 1. Effect of LPS and dexmedetomidine pretreatment on cytotoxicity in WISH cells was measured by MTT assay. Data are presented as mean \pm SD. All experiments were repeated three times. DEX: dexmedetomidine.

\section{NO production in LPS-treated WISH cells after dexmedetomidine pretreatment}

NO production was measured as nitrites by the Griess-reaction microassay. WISH cells basally released nitrites into the culture medium. The release of nitrites was not affected by LPS and pretreatment with dexmedetomidine at all concentrations (Figure 2).

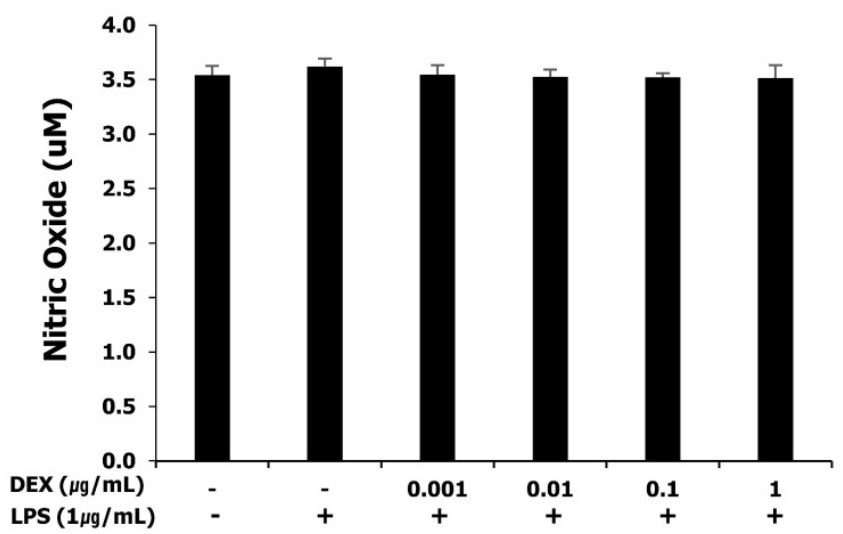

Figure 2. Effect of dexmedetomidine pretreatment on NO production in LPS-treated WISH cells was investigated by the Griess-reaction microassay. Data are presented as mean $\pm \mathrm{SD}$. All experiments were repeated three times. DEX: dexmedetomidine.

\section{Effect of dexmedetomidine pretreatment on COX-2 and PGE $_{2}$ expression following LPS-} induced inflammatory response in WISH cells

The mRNA expression levels of COX-2 and $\mathrm{PGE}_{2}$ were determined using RT-PCR. The mRNA expression of COX-2 in WISH cells significantly increased to $1.37 \pm 0.06$ following exposure to 1 $\mu \mathrm{g} / \mathrm{mL}$ LPS compared to that of the control $(p<0.001)$. The increased mRNA expression of COX-2 was significantly reduced by dexmedetomidine pretreatments at all concentrations $(0.93 \pm 0.02$ at 0.001 $\mu \mathrm{g} / \mathrm{mL}, p<0.001 ; 1.15 \pm 0.08$ at $0.01 \mu \mathrm{g} / \mathrm{mL}, p<0.05$; $1.25 \pm 0.12$ at $0.1 \mu \mathrm{g} / \mathrm{mL}, p<0.05 ; 1.14 \pm 0.04$ at 1 $\mu \mathrm{g} / \mathrm{mL}, p<0.01)$. The mRNA expression of $\mathrm{PGE}_{2}$ significantly increased to $1.3 \pm 0.13$ following exposure to $1 \mu \mathrm{g} / \mathrm{mL}$ LPS compared to the control $(p<0.05)$. The pretreatment of LPS-treated WISH cells with dexmedetomidine significantly reduced the mRNA expression levels of $\mathrm{PGE}_{2}$ at all concentrations $(0.85 \pm 0.03$ at $0.001 \mu \mathrm{g} / \mathrm{mL}, p<0.01 ; 1.02 \pm 0.09$ at 0.01 $\mu \mathrm{g} / \mathrm{mL}, p<0.05 ; 0.99 \pm 0.06$ at $0.1 \mu \mathrm{g} / \mathrm{mL}, p<0.05 ; 0.84 \pm$ 0.07 at $1 \mu \mathrm{g} / \mathrm{mL}, p<0.01)$ compared to the LPS-treated group (Figure 3A).

The protein expression of COX-2 and $\mathrm{PGE}_{2}$ was analyzed by western blotting (Figure 3B); the results were in concordance with those obtained for the mRNA expression of COX-2 and PGE 2 . There was a significant increase in the protein expression of COX-2 (1.54 \pm 0.31) and $\mathrm{PGE}_{2}(1.47 \pm 0.28)$ following treatment with $1 \mu \mathrm{g} / \mathrm{mL}$ LPS compared to the control $(p<0.05)$. The protein expression of COX-2 decreased significantly when the cells were pretreated with dexmedetomidine $(0.10 \pm 0.23$ at $0.001 \mu \mathrm{g} / \mathrm{mL} ; 0.95 \pm$ 0.38 at $0.01 \mu \mathrm{g} / \mathrm{mL} ; 1.01 \pm 0.26$ at $0.1 \mu \mathrm{g} / \mathrm{mL} ; 0.89 \pm$ 0.12 at $1 \mu \mathrm{g} / \mathrm{mL}, p<0.05)$, compared to the LPS-treated group. The protein expression of $\mathrm{PGE}_{2}$ also decreased by dexmedetomidine pretreatment at all concentrations and the differences compared to the LPS-treated group were statistically significant $(0.99 \pm$ 0.32 at $0.001 \mu \mathrm{g} / \mathrm{mL}, p<0.05 ; 0.59 \pm 0.10$ at $0.01 \mu \mathrm{g} / \mathrm{mL}$, $p<0.01 ; 0.84 \pm 0.30$ at $0.1 \mu \mathrm{g} / \mathrm{mL}, p<0.05 ; 0.44 \pm 0.22$ at $1 \mu \mathrm{g} / \mathrm{mL}, p<0.01$ ).

\section{Expression of inflammatory cytokines (TNF- $\alpha$ and IL-1 $\beta$ ) in LPS-treated WISH cells following dexmedetomidine pretreatment}

To investigate the effect of dexmedetomidine pretreatment on the expression of inflammatory cytokines, the mRNA expression of TNF- $\alpha$ and IL-1 $\beta$ was measured using RT-PCR. As shown in Figure 4, the treatment of WISH cells with $1 \mu \mathrm{g} / \mathrm{mL}$ LPS significantly increased the mRNA expression levels of TNF- $\alpha(1.33 \pm 0.10, p<0.001)$ and IL-1 $\beta(1.56 \pm 0.16$, $p<0.01)$, compared to the control. Pretreatment with dexmedetomidine significantly decreased the LPS-induced mRNA expression of TNF-a $(0.91 \pm 0.05$ at $0.001 \mu \mathrm{g} / \mathrm{mL}, p<0.001 ; 0.91 \pm 0.05$ at $0.01 \mu \mathrm{g} / \mathrm{mL}$, $p<0.001 ; 1.05 \pm 0.16$ at $0.1 \mu \mathrm{g} / \mathrm{mL}, p<0.05 ; 0.85 \pm 0.12$ at $1 \mu \mathrm{g} / \mathrm{mL}, p<0.001)$ and IL-1 $\beta(0.95 \pm 0.02$ at 0.001 $\mu \mathrm{g} / \mathrm{mL}, p<0.01 ; 1.10 \pm 0.21$ at $0.01 \mu \mathrm{g} / \mathrm{mL} ; 0.97 \pm 0.26$ at $0.1 \mu \mathrm{g} / \mathrm{mL} ; 0.96 \pm 0.17$ at $1 \mu \mathrm{g} / \mathrm{mL}, p<0.05)$ at all concentrations. 
A

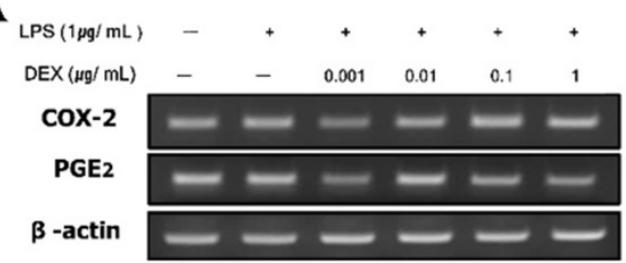

$\operatorname{cox}-2$

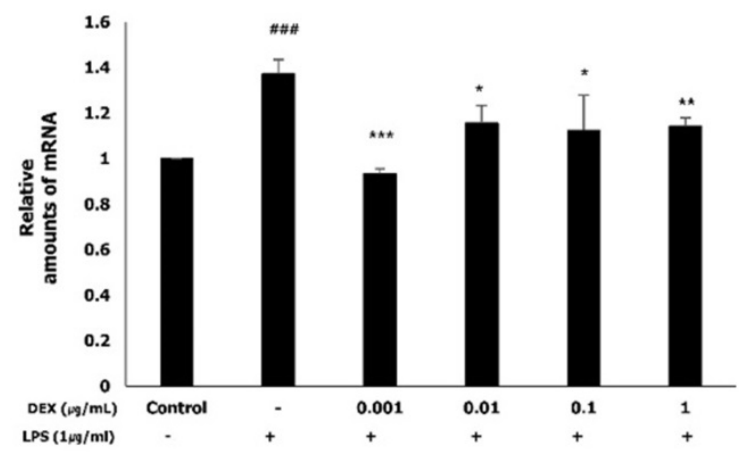

PGE2

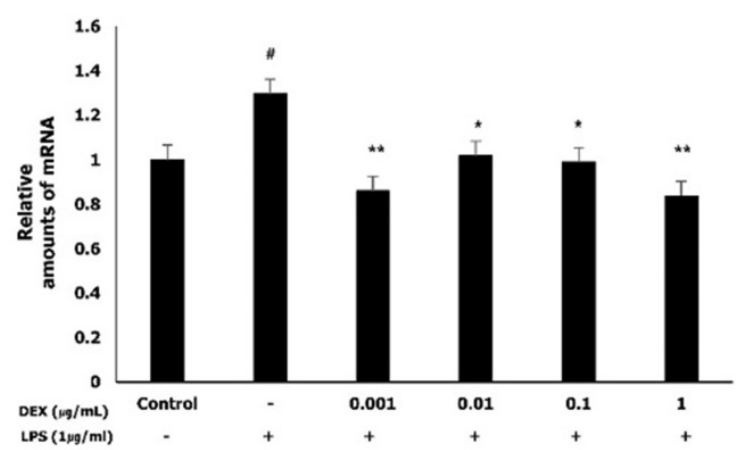

B

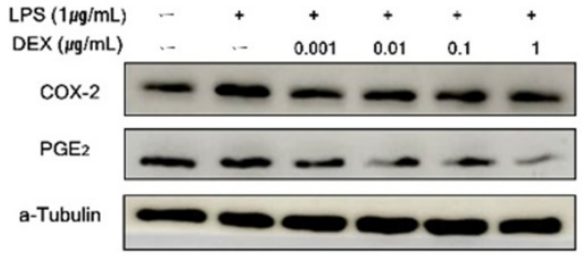

$\operatorname{cox}-2$

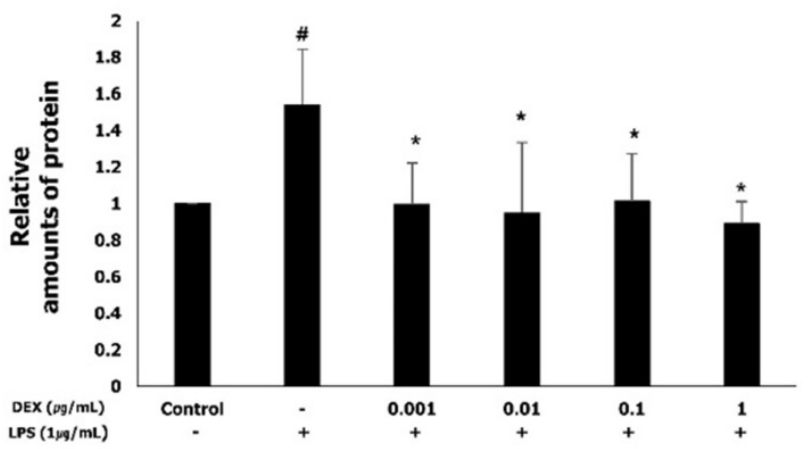

PGE2

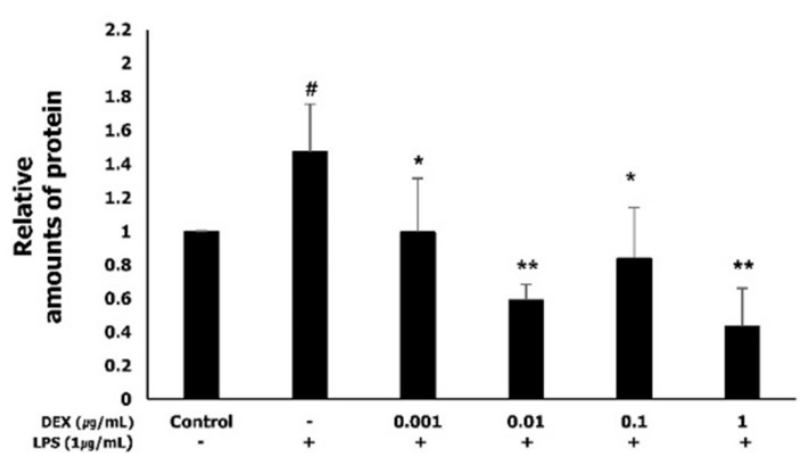

Figure 3. To evaluate the effects of dexmedetomidine pretreatment on the expressions of COX-2 and PGE $E_{2}$ WISH cells were pretreated with dexmedetomidine (0.001-1 $\mu \mathrm{g} / \mathrm{mL}$ ) and after then treated with $1 \mu \mathrm{g} / \mathrm{ml}$ LPS. (A) The mRNA expressions of COX-2 and PGE 2 were determined using RT-PCR analysis. Relative density of the mRNA expression of COX-2 and $\mathrm{PGE}_{2}$ was normalized by $\beta$-actin. (B) The protein expressions of COX-2 and $P G E_{2}$ were evaluated by western blotting. Relative density analysis was performed using Image] software and normalized by $\alpha$-tubulin. Data are mean \pm SD of three independent experiments. $\# P<0.05$, \#\#P<0.001 versus control group; $* P<0.05$, $* * P<0.01, * * * P<0.001$ versus LPS group. DEX: dexmedetomidine.

Role of p38 and NF-KB in the antiinflammatory effect of dexmedetomidine on LPS-treated WISH cells

To determine whether the anti-inflammatory effect of dexmedetomidine was mediated via the MAPK or NF-kB signaling pathways, we examined the activation of p38 and NF-kB by western blotting. LPS treatment significantly increased the protein expression of phospho-p38 $(2.97 \pm 0.99, p<0.01)$ and phospho-NF-kB $(1.94 \pm 0.43, p<0.01)$, the activated forms of p38 and NF-kB, respectively, compared to the control (Figure 5A and $\mathbf{B}$ ). The protein expression of phospho-p38 was significantly decreased following pretreatment with $0.1 \mu \mathrm{g} / \mathrm{mL}(1.32 \pm 0.61, p<0.01)$ and $1 \mu \mathrm{g} / \mathrm{mL}(1.51 \pm 0.34, p<0.01)$ dexmedetomidine compared to the LPS-treated group (Figure 5A). As shown in Figure 5B, pretreatment with dexmedetomidine at concentrations of $0.01 \mu \mathrm{g} / \mathrm{mL}$ (1.19 $\pm 0.08, p<0.05), 0.1 \mu \mathrm{g} / \mathrm{mL}(0.78 \pm 0.25, p<0.05)$, and $1 \mu \mathrm{g} / \mathrm{mL}(0.67 \pm 0.13, p<0.01)$ significantly decreased the LPS-induced expression of phosphoNF-KB. These results suggested that pretreatment with dexmedetomidine suppresses the activation of p38 and NF-KB.

\section{Discussion}

The present study demonstrated that pretreatment with dexmedetomidine attenuates the LPS-induced expression of COX-2, $\mathrm{PGE}_{2}$, and inflammatory cytokines in human amnion-derived WISH cells. To the best of our knowledge, this is the first study to investigate the effect of dexmedetomidine on the inflammatory response 
using WISH cells. The WISH epithelial cells are a good in vitro model to study the physiological functions of cells in the amnion. At the onset of labor, the levels of pro-inflammatory cytokines and chemokines increase in the epithelial cells of the amnion [24]. WISH cells are the ideal candidate for in vitro studies for investigating the factors that trigger labor and the modulation of $\mathrm{PGE}_{2}$ release by various agonists $[25,26]$.

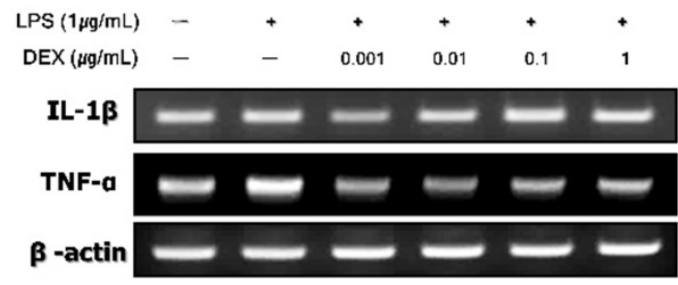

\section{IL-1及}

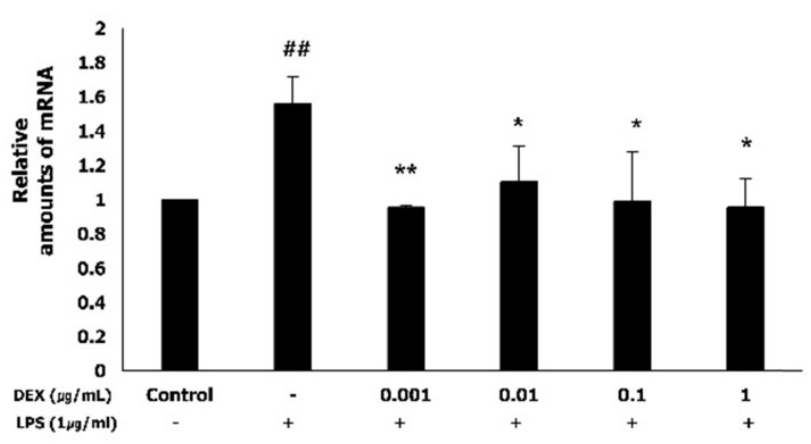

TNF-a

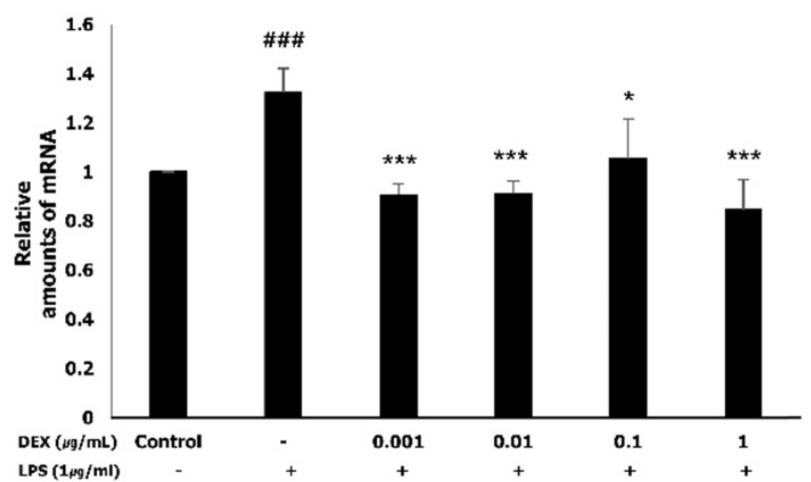

Figure 4. The mRNA expressions of TNF- $\alpha$ and IL-1 $\beta$ by dexmedetomidine pretreatment in LPS-treated WISH cells were measured using RT-PCR. Relative mRNA level was normalized by $\beta$-actin and presented as mean \pm SD of three

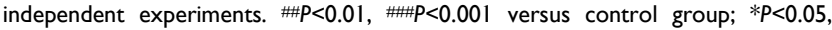
$* * P<0.01$, $* * * P<0.001$ versus LPS group. DEX: dexmedetomidine.

In this study, pretreatment with dexmedetomidine was found to have an anti-inflammatory effect on LPS-stimulated WISH cells suggesting that dexmedetomidine could antagonize the uterine contraction resulting from inflammation. Some studies have explored the effect of dexmedetomidine on inflammatory responses. Kang and coworkers [27] reported that the administration of dexmedetomidine during laparoscopic cholecystectomy decreases the secretion of inflammatory cytokines, post-operative leukocyte counts, and the levels of C-reactive protein. Studies by Taniguchi and coworkers [28] and Qiao and coworkers [29] demonstrated that dexmedetomidine reduces the concentrations of TNF- $\alpha$ and IL-6, and ameliorates mortality in rats with endotoxin or cecal ligation and intestinal puncture-induced sepsis. However, another study reported that dexmedetomidine increases uterine contraction at a plasma concentration of $1 \times 10^{-9} \mathrm{~g} / \mathrm{mL}$ [30]. Karaman and coworkers [31] also demonstrated that dexmedetomidine increases the amplitude, frequency, and area under the curve of rat myometrial contractions in a dose-dependent manner. It is therefore difficult to be certain that dexmedetomidine suppresses uterine contraction by inhibiting the inflammatory response. However, it is known that dexmedetomidine has anti-inflammatory effects on WISH cells. Further studies are necessary for verifying the effect of dexmedetomidine on uterine contraction.

We treated WISH cells with LPS, a component of the cell wall of gram-negative bacteria, to induce the inflammatory response. LPS stimulates the innate immune response and is consequently recognized by LPS-binding protein (LBP) in the serum. The binding of LBP with LPS promotes the transfer to CD14 which separates the LPS and presents it to the TLR4 complex $[32,33]$. TLRs are a family of innate immune receptors that serve as major sensors of bacterial pathogens in murine and human placenta [34-36]. TLR4 is the primary receptor for transducing the LPS signal in human amniotic epithelial cells [37]. Following the recognition of LPS by TLR4 in the amnion, the downstream signaling cascade is activated and leads to the activation of MAPK and NF- $\mathrm{kB}$, and the induction of pro-inflammatory cytokine gene expression $[38,39]$.

The p38 MAPKs play a major role during inflammatory responses and are rapidly phosphorylated following LPS stimulation. The p38 pathway is a key regulator of the biosynthesis of pro-inflammatory cytokines including IL-1 $\beta$ and TNF-a $[40,41]$. p38a is the main isoform of p38 MAPKs and partially regulates the production of COX-2 [42]. NF-KB is a principal transcriptional factor involved in inflammatory responses and is translocated from the cytoplasm to the nucleus following activation. In the nucleus, the activated 
A
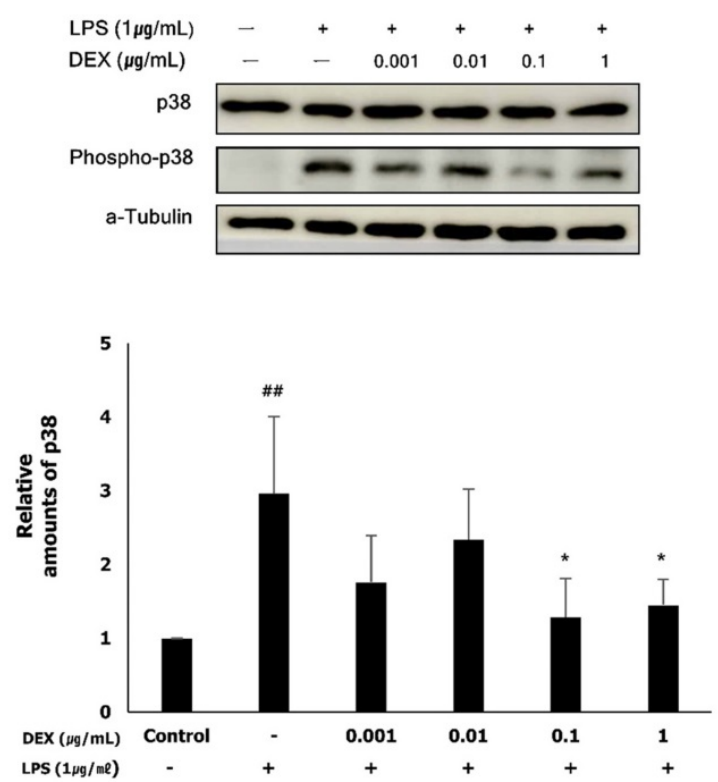

B
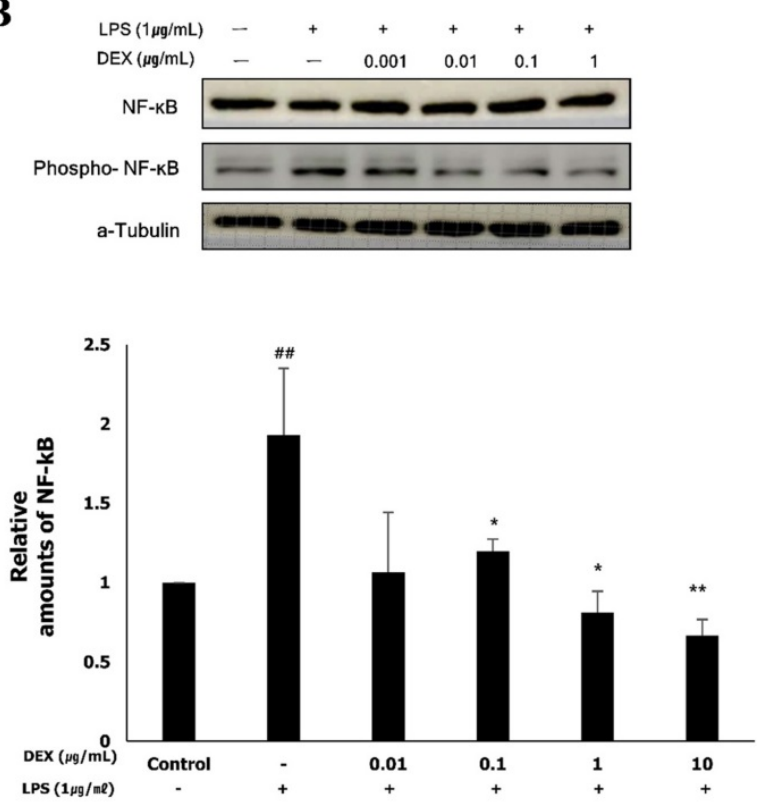

Figure 5. The activation of $\mathrm{p} 38$ and NF-KB by dexmedetomidine pretreatment in LPS-treated WISH cells were evaluated using western blotting. To investigate the activation of $\mathrm{p} 38$ and NF-KB, the protein expressions of phospho-p38 and phospho-NF-KB were measured. (A) Relative amounts of phospho-p38 protein were analyzed by triplicate experiments and normalized by $\mathrm{P} 38$. (B) Relative amounts of phospho-NF-KB protein were analyzed by triplicate experiments and normalized by NF-KB. \#P<0.01 versus control group; $* P<0.05, * * P<0.01$ versus LPS group. DEX: dexmedetomidine.

NF-kB binds to the promoter regions of COX-2, IL-1 $\beta$, and TNF- $\alpha$ genes, and induces their expression $[43,44]$. It has been established that the expression of the COX-2 gene depends on NF- $\mathrm{kB}$ and in turn accelerates the production of PGs that induce cervical ripening and the onset of labor [45]. In our experiments, pretreatment with dexmedetomidine suppressed the LPS-induced expression of phospho-p38 and phospho-NF-kB mRNA. The LPS-induced expression of COX-2, $\mathrm{PGE}_{2}$, and inflammatory cytokines (IL-1 $\beta$ and TNF- $\alpha$ ) was attenuated by pretreatment with dexmedetomidine. Therefore, the results of this study imply that pretreatment with dexmedetomidine restricts the LPS-induced expression of COX-2, PGE 2 IL-1 $\beta$, and TNF- $\alpha$ by suppressing the activation of p38 MAPK and NF-kB.

In the present in vitro study, WISH cells were treated with dexmedetomidine at concentrations ranging between 0.001 and $1 \mu \mathrm{g} / \mathrm{mL}(0.005$ to $5 \mu \mathrm{M})$, based on a previous study [46]. In that study, the cells were treated with dexmedetomidine at concentrations of $0.0001,0.001,0.01,0.1$, and $1 \mu \mathrm{g} / \mathrm{mL}$. Reportedly the plasma concentrations of dexmedetomidine in clinical use ranges from 0.49 to $8 \mathrm{ng} / \mathrm{mL}$ [47]. Ebert and coworkers reported that the plasma concentrations of dexmedetomidine for inducing a mild to moderate sedative effect range between 0.7 and $1.2 \mathrm{ng} / \mathrm{mL}$. Deep sedation is thought to arise at plasma concentrations above $1.9 \mathrm{ng} / \mathrm{mL}[48,48]$. Another study reported that $0.1,1$, and $10 \mu \mathrm{M}$ of dexmedetomidine are high concentrations for clinical use, and $0.001 \mu \mathrm{M}$ of dexmedetomidine is the lowest concentration for clinical use [50]. Therefore, the concentration of dexmedetomidine used in this study fall within the concentration range used in the clinics.

Although the effects of dexmedetomidine on the expression of inflammatory substances in LPS-stimulated WISH cells were evaluated under normoxic conditions, the inflammation is often accompanied by hypoxia owing to the high oxygen consumption [51]. Therefore, it is uncertain whether our experiments were conducted under normoxia or hypoxia. The role of hypoxia in the inflammatory response is still unclear. To demonstrate the effect of hypoxia on the inflammatory response in the amnion, further research is needed.

In this study, we used human amnion-derived WISH cells as a model for studying the effect of dexmedetomidine on the expression of inflammatory substances involved in preterm labor. In previous studies, various animal models and human-tissue models were used to examine the effect of inflammation on preterm labor. Despite significant differences in reproductive biology to humans, animal models such as nonhuman primates, sheep, and mice have been useful to study preterm labor [52-54]. Some studies used human amnion epithelial cells separated from the term placenta delivered by elective cesarean section to analyze the inflammatory effects of various agents on amnion [55,56].

In conclusion, pretreatment of WISH cells with dexmedetomidine attenuated the LPS-induced expression of inflammatory substances including 
COX-2, PGE 2, TNF- $\alpha$, and IL-1 $\beta$. This antiinflammatory effect of dexmedetomidine suggests that dexmedetomidine may help reduce the uterine contractions caused by the inflammatory response during pregnancy. The present in vitro study further demonstrated that dexmedetomidine mediates these anti-inflammatory effects by suppressing the activation of p38 and NF-kB.

\section{Acknowledgements}

This study was supported by Dental Research Institute (PNUDH-DRI 2018-03), Pusan National University Dental Hospital.

\section{Competing Interests}

The authors have declared that no competing interest exists.

\section{References}

1. Norwitz ER, Starkey PM, Lopez Bernal A. Prostaglandin D2 production by term human decidua: cellular origins defined using flow cytometry. Obstet. Gynecol. 1992;80:440-5.

2. Nancy $P$, Erlebacher A. T cell behavior at the maternal-fetal interface. Int.J.Dev.Biol. 2014;58:189-98

3. Romero R, Munoz H, Gomez R, Parra M, Polanco M, Valverde V, et al. Increase in prostaglandin bioavailability precedes the onset of human parturition. Prostaglandins Leukot. Essent. Fatty Acids. 1996;54:187-91.

4. Olson DM, Mijovic JE, Sadowsky DW. Control of human parturition. Semin. Perinatol. 1995; 19:52-63.

5. Gibb W. The role of prostaglandins in human parturition. Ann. Med. 1998;30:235-41.

6. Ledingham MA, Thomson AJ, Greer IA, Norman JE. Nitric oxide in parturition. BJOG. 2000;107:581-93.

7. Yallampalli C, Dong YL, Gangula PR, Fang L. Role and regulation of nitric oxide in the uterus during pregnancy and parturition. J. Soc. Gynecol. Investig. 1998;5:58-67.

8. Goldenberg RL, Hauth JC, Andrews WW. Intrauterine infection and preterm delivery. N. Engl. J. Med. 2000;342:1500-7.

9. Crupi R, Palma E, Siracusa R, Fusco R, Gugliandolo E, Cordaro M, et al. Protective Effect of Hydroxytyrosol Against Oxidative Stress Induced by the Ochratoxin in Kidney Cells: in vitro and in vivo Study. Front.Vet.Sci. 2020;7:136.

10. Anderson KV. Toll signaling pathways in the innate immune response. Curr.Opin.Immunol. 2000;12:13-9.

11. Chuang T, Ulevitch RJ. Identification of hTLR10: a novel human Toll-like receptor preferentially expressed in immune cells. Biochim.Biophys.Acta. 2001;1518:157-61.

12. Zheng S, Lin Z, Liu Z, Liu Y, Wu W. Lipopolysaccharide Mediates the Destruction of Intercellular Tight Junction among Renal Tubular Epithelial Cells via RhoT1/SMAD-4/JAM-3 Pathway. Int. J. Med. Sci. 2018;15:595-602.

13. Sweet MJ, Hume DA. Endotoxin signal transduction in macrophages. J. Leukoc. Biol. 1996;60:8-26.

14. Dowling D, Hamilton CM, O'Neill SM. A comparative analysis of cytokine responses, cell surface marker expression and MAPKs in DCs matured with LPS compared with a panel of TLR ligands. Cytokine. 2008;41:254-62.

15. Gugliandolo E, Fusco R, Ginestra G, D'amico R, Bisignano C, Mandalari G, et al. Involvement of TLR4 and PPAR-alpha Receptors in Host Response and NLRP3 Inflammasome Activation, Against Pulmonary Infection With Pseudomonas Aeruginosa. Shock . 2019;51:221-7.

16. Qureshi ST, Lariviere L, Leveque G, Clermont S, Moore KJ, Gros P, et al. Endotoxin-tolerant mice have mutations in Toll-like receptor 4 (Tlr4). J. Exp. Med. 1999;189:615-25.

17. Su X, Chen O, Chen W, Chen T, Li W, Li Y, et al. Mycoepoxydiene inhibits activation of BV2 microglia stimulated by lipopolysaccharide through suppressing NF-kappaB, ERK $1 / 2$ and toll-like receptor pathways. Int. Immunopharmacol. 2014;19:88-93.

18. Kim SF. The nitric oxide-mediated regulation of prostaglandin signaling in medicine. Vitam. Horm. 2014;96:211-45.

19. Kaur M, Singh PM. Current role of dexmedetomidine in clinical anesthesia and intensive care. Anesth. Essays Res. 2011;5:128-33.

20. Maze M, Scarfini C, Cavaliere F. New agents for sedation in the intensive care unit. Crit. Care Clin. 2001;17:881-97.

21. Qiao H, Sanders RD, Ma D, Wu X, Maze M. Sedation improves early outcome in severely septic Sprague Dawley rats. Crit. Care. 2009;13:R136.
22. Venn RM, Bryant A, Hall GM, Grounds RM. Effects of dexmedetomidine on adrenocortical function, and the cardiovascular, endocrine and inflammatory responses in post-operative patients needing sedation in the intensive care unit. Br. J. Anaesth. 2001;86:650-6.

23. Mattingly JE, D'Alessio J, Ramanathan J. Effects of obstetric analgesics and anesthetics on the neonate: a review. Paediatr. Drugs. 2003;5:615-27.

24. Elliott CL, Loudon JA, Brown N, Slater DM, Bennett PR, Sullivan MH. IL-1beta and IL-8 in human fetal membranes: changes with gestational age, labor, and culture conditions. Am. J. Reprod. Immunol. 2001;46:260-7.

25. Pavan B, Buzzi M, Ginanni-Corradini F, Ferretti ME, Vesce F, Biondi C. Influence of oxytocin on prostaglandin E2, intracellular calcium, and cyclic adenosine monophosphate in human amnion-derived (WISH) cells. Am. J. Obstet. Gynecol. 2000;183:76-82.

26. Pavan B, Biondi C, Ferretti ME, Lunghi L, Paganetto G. 17beta-estradiol modulates prostaglandin E2 release from human amnion-derived wish cells. Biol. Reprod. 2001;64:1677-81.

27. Kang SH, Kim YS, Hong TH, Chae MS, Cho ML, Her YM, et al. Effects of dexmedetomidine on inflammatory responses in patients undergoing laparoscopic cholecystectomy. Acta Anaesthesiol.Scand. 2013;57:480-7.

28. Taniguchi T, Kidani Y, Kanakura H, Takemoto Y, Yamamoto K. Effects of dexmedetomidine on mortality rate and inflammatory responses to endotoxin-induced shock in rats. Crit. Care Med. 2004;32:1322-6.

29. Qiao H, Sanders RD, Ma D, Wu X, Maze M. Sedation improves early outcome in severely septic Sprague Dawley rats. Crit. Care. 2009;13:R136.

30. Sia AT, Kwek K, Yeo GS. The in vitro effects of clonidine and dexmedetomidine on human myometrium. Int.J.Obstet.Anesth. 2005;14:104-7.

31. Karaman S, Evren V, Firat V, Cankayali I. The effects of dexmedetomidine on spontaneous contractions of isolated gravid rat myometrium. Adv. Ther. 2006;23:238-43.

32. Triantafilou M, Triantafilou K. Lipopolysaccharide recognition: CD14, TLRs and the LPS-activation cluster. Trends Immunol. 2002;23:301-4.

33. Pugin J, Schurer-Maly CC, Leturcq D, Moriarty A, Ulevitch RJ, Tobias PS. Lipopolysaccharide activation of human endothelial and epithelial cells is mediated by lipopolysaccharide-binding protein and soluble CD14. Proc. Natl. Acad. Sci. U.S.A. 1993:90:2744-8.

34. Beutler B. Innate immune responses to microbial poisons: discovery and function of the Toll-like receptors. Annu. Rev. Pharmacol. Toxicol. 2003;43:609-28

35. Medzhitov R, Preston-Hurlburt P, Janeway CA. A human homologue of the Drosophila Toll protein signals activation of adaptive immunity. Nature. 1997:388:394-7

36. Abrahams VM, Mor G. Toll-like receptors and their role in the trophoblast. Placenta. 2005;26:540-7.

37. Hoshino K, Takeuchi O, Kawai T, Sanjo H, Ogawa T, Takeda Y, et al. Cutting edge: Toll-like receptor 4 (TLR4)-deficient mice are hyporesponsive to lipopolysaccharide: evidence for TLR4 as the Lps gene product. J. Immunol. 1999;162:3749-52.

38. Akira S, Takeda K. Toll-like receptor signalling. Nat. Rev. Immunol. 2004;4:499-511.

39. Holmlund U, Cebers G, Dahlfors AR, Sandstedt B, Bremme K, Ekstrom ES, et al. Expression and regulation of the pattern recognition receptors Toll-like receptor- 2 and Toll-like receptor- 4 in the human placenta. Immunology. 2002;107:145-51.

40. Lee JC, Laydon JT, McDonnell PC, Gallagher TF, Kumar S, Green D, et al. A protein kinase involved in the regulation of inflammatory cytokine biosynthesis. Nature. 2029;372:739-46.

41. Byeon SE, Lee J, Yoo BC, Sung GH, Kim TW, Park HJ, et al. p38-targeted inhibition of interleukin-12 expression by ethanol extract from Cordyceps bassiana in lipopolysaccharide-activated macrophages. Immunopharmacol. Immunotoxicol. 2011;33:90-6.

42. Ridley SH, Dean JL, Sarsfield SJ, Brook M, Clark AR, Saklatvala J. A p38 MAP kinase inhibitor regulates stability of interleukin-1-induced cyclooxygenase-2 mRNA. FEBS Lett. 1998;439:75-80.

43. Bacher S, Schmitz ML. The NF-kappaB pathway as a potential target for autoimmune disease therapy. Curr. Pharm. Des. 2004;10:2827-37.

44. Min KJ, Lee JT, Joe EH, Kwon TK. An IkappaBalpha phosphorylation inhibitor induces heme oxygenase-1(HO-1) expression through the activation of reactive oxygen species (ROS)-Nrf2-ARE signaling and ROS-PI3K/Akt signaling in an NF-kappaB-independent mechanism. Cell. Signal. 2011;23:1505-13.

45. Allport VC, Pieber D, Slater DM, Newton R, White JO, Bennett PR. Human labour is associated with nuclear factor-kappaB activity which mediates cyclo-oxygenase-2 expression and is involved with the 'functional progesterone withdrawal'. Mol. Hum. Reprod. 2001;7:581-6.

46. Sia AT, Kwek K, Yeo GS. The in vitro effects of clonidine and dexmedetomidine on human myometrium. Int. J. Obstet. Anesth. 2005;14:104-7.

47. Weerink MAS, Struys MMRF, Hannivoort LN, Barends CRM, Absalom AR, Colin P. Clinical Pharmacokinetics and Pharmacodynamics of Dexmedetomidine. Clin. Pharmacokinet. 2017; 56:893-913.

48. Ebert TJ, Hall JE, Barney JA, Uhrich TD, Colinco MD. The effects of increasing plasma concentrations of dexmedetomidine in humans. Anesthesiology. 2000;93:382-94. 
49. Bloor BC, Ward DS, Belleville JP, Maze M. Effects of intravenous dexmedetomidine in humans. II. Hemodynamic changes. Anesthesiology. 1992;77:1134-42.

50. Guo F, Ding Y, Yu X, Cai X. Effect of dexmedetomidine, midazolam, and propofol on lipopolysaccharide-stimulated dendritic cells. Exp. Ther. Med. 2018;15:5487-94.

51. Mitchell BF, Taggart MJ. Are animal models relevant to key aspects of human parturition? Am. J. Physiol. Regul. Integr. Comp. Physiol. 2009;297:525.

52. Carter AM. Animal models of human placentation--a review. Placenta. 2007; 28(Suppl A):41.

53. Bezold KY, Karjalainen MK, Hallman M, Teramo K, Muglia LJ. The genomics of preterm birth: from animal models to human studies. Genome Med. 2013;5:34.

54. Moore JJ, Dubyak GR, Moore RM, Vander Kooy D. Oxytocin activates the inositol-phospholipid-protein kinase-C system and stimulates prostaglandin production in human amnion cells. Endocrinology. 1988;123:1771-7.

55. Kim JD, Ahn BM, Joo BS, Kwon JY, Chung HJ, Yu SB. Effect of propofol on prostaglandin E2 production and prostaglandin synthase-2 and cyclooxygenase-2 expressions in amniotic membrane cells. J. Anesth. 2014;28:911-8.

56. Szukiewicz D, Kochanowski J, Mittal TK, Pyzlak M, Szewczyk G, Cendrowski K. Chorioamnionitis (ChA) modifies CX3CL1 (fractalkine) production by human amniotic epithelial cells (HAEC) under normoxic and hypoxic conditions. J. Inflamm. (Lond). 2014; 11:12,12. eCollection 2014. 